\title{
CORRECTION
}

\section{Correction to: The impact of COVID-19 on systemic anticancer treatment delivery in Scotland}

Mark A. Baxter (ID, John Murphy, David Cameron, Judith Jordan, Christine Crearie, Christina Lilley, Azmat Sadozye, Mary Maclean, Peter Hall (D, Angela Phillips, Alex Greger, Jude Madeleine and Russell D. Petty

British Journal of Cancer (2021) 124:1745; https://doi.org/10.1038/s41416-021-01298-w

Correction to: British Journal of Cancer https://doi.org/10.1038/ s41416-021-01262-8, published online 2 February 2021

The article The impact of COVID-19 on systemic anticancer treatment delivery in Scotland, written by Mark A. Baxter, John Murphy, David Cameron, Judith Jordan, Christine Crearie, Christina Lilley, Azmat Sadozye, Mary Maclean, Peter Hall, Angela Phillips, Alex Greger, Jude Madeleine and Russell D. Petty, was originally published electronically on the publisher's internet portal on 2 February 2021 without open access. With the author(s)' decision to opt for Open Choice the copyright of the article changed on 29th January 2021 to $\odot$ The Author(s) 2021 and the article is forthwith distributed under a Creative Commons Attribution 4.0 International License, which permits use, sharing, adaptation, distribution, and reproduction in any medium or format, as long as you give appropriate credit to the original author(s) and the source, provide a link to the Creative Commons licence, and indicate if changes were made.

The images or other third party material in this article are included in the article's Creative Commons licence, unless indicated otherwise in a credit line to the material. If material is not included in the article's Creative Commons licence and your intended use is not permitted by statutory regulation or exceeds the permitted use, you will need to obtain permission directly from the copyright holder.

To view a copy of this licence, visit http://creativecommons.org/ licenses/by/4.0.

(i) Open Access This article is licensed under a Creative Commons Attribution 4.0 International License, which permits use, sharing, adaptation, distribution and reproduction in any medium or format, as long as you give appropriate credit to the original author(s) and the source, provide a link to the Creative Commons license, and indicate if changes were made. The images or other third party material in this article are included in the article's Creative Commons license, unless indicated otherwise in a credit line to the material. If material is not included in the article's Creative Commons license and your intended use is not permitted by statutory regulation or exceeds the permitted use, you will need to obtain permission directly from the copyright holder. To view a copy of this license, visit http://creativecommons. org/licenses/by/4.0/.

(c) The Author(s) 2021 